\title{
Analysis of Factors Affecting Horizontal Displacement of Pier Top of High-Pile and High-Pier Bridge
}

\author{
Zhu Mei-liang ${ }^{1}$, Zhang Li-qing ${ }^{2,3,}$, , Huang Sen-yan ${ }^{1}$, Song Chun-xia ${ }^{2}$ \\ ${ }^{1}$ Hangzhou Qianhuang Expressway Co., Ltd., Hangzhou 310030, China \\ ${ }^{2}$ Research Institute of Highway, Ministry of Transport, Beijing 100088, China \\ ${ }^{3}$ China-Road Transportation Verification \& Inspection Hi-Tech Co., Ltd., Beijing 100088, China
}

\begin{abstract}
The excessive longitudinal horizontal displacement of pier top has become one of the common defects of high-pier bridge, which seriously affects the safety of the bridge structure. In order to determine the influencing factors of the horizontal displacement of the pier top of high-pile and high-pier bridges, this paper establishes the finite element model of the whole bridge based on the high-pile and high-pier bridge of the Qianhuang Expressway, and considers the influence of dead load, vehicle load, vehicle braking force, temperature load, bearing friction coefficient, and bearing under eccentric compression on the horizontal displacement of the pier top. By comparing and analyzing the law of various factors influence on the horizontal displacement of the pier top, the main causes of the horizontal displacement of the pier top of highpile and high-pier bridges are summarized, which can provide reference for the analysis of pier top deviation of similar high-pile and high-pier bridges.
\end{abstract}

\section{Introduction}

With the development of Chinese economy, construction of highway bridges in mountainous regions has been implemented increasingly, many highways have to cross deep gullies and river valleys. Therefore, high-pile and high-pier bridge has been widely applied ${ }^{[1]}$. However, according to the survey and inspection statistics in bridge operation stage, longitudinal horizontal deviation of the pier top has become a common defect on the high-pile and high-pier bridge. Piers with obvious longitudinal horizontal deviation also have other defects such as bearing exceeding slip displacement limit, bearing shear failure, main beam sliding, pier annular crack etc. These defects seriously affect the bridge safety ${ }^{[2-5]}$. As to the deviation of pier top of high-pier bridge in operation stage, Tian Shiqing et al. ${ }^{[6]}$ believe that there is an obvious relationship between the pier deviation and the slope of beam-bearing contact surface caused by the bearing installation defects. The more the contact surface is, the greater the offset value of the bridge pier toward the upslope direction is. Wu Hongye [7] summarized the influence of bearing installation defects on the stress of high-pier bridge and concluded that the non-level sliding surface of the pot bearing is the direct cause of pier top deviation. Sun Wenlong et al. ${ }^{[8]}$ analysed the deviation of a certain bridge pier column and believed that because the bearings were not properly levelled in installation, resulting in the horizontal force generated by the bridge superstructure with longitudinal slope, which is the main cause of pier top deviation. Wang Lihong et al. ${ }^{[9]}$ analysed and summarised the law of influence of design parameters on the pier top deviation of high-pier bridge. For the causes of pier top deviation of high-pier bridge, the existing literature are mainly based on the pier top deviation defects of high-pier bridge in mountainous area and analysed from the aspects of bearing defects during installation and operation stage.

In this paper, based on a high-pile and high-pier bridge in the Chun'an Section of Liyang-Ningde National Expressway of Zhejiang Province (hereinafter referred to as the "Qianhuang Expressway Chun'an Section"), a finite element model of high-pile and high-pier bridge is established. By comparing the influence on the horizontal pier top displacement caused by such factors as design loads (dead load, vehicle load, vehicle braking load and temperature load), bearing friction coefficient, eccentric bearing compression et. This paper summarizes the main factors affecting the horizontal pier top deviation of the high-pile and high-pier bridge.

\section{Project profile}

In this paper, a typical high-piled and high-pier bridge (2 $\times(3 \times 40) \mathrm{m}+4 \times 40 \mathrm{~m}+3 \times 40 \mathrm{~m})$ crossing reservoir area in Chun'an section of Silian Qianhuang expressway was selected. The superstructure is simply-supported-tocontinuous beam, prefabricated prestressed concrete Tbeam, column abutment, two types of pier structure: cap beam connecting to double-column pier and cap beam connecting to solid pier. NO. $1,2,3,5,10,11,12$ piers are double-column pier and NO. 4, 6, 7, 8, 9 piers are solid pier. Pile foundation for both abutment and pier. GPZ (2009) Pot-type elastomeric pad bearing was adopted for

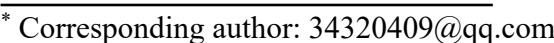


T beams. bearing of 3.5 series is used on top of the Continuous pier, while 2.5 series is used on top of the noncontinuous pier. Vehicle design load is highway grade I.
Parameters of some piers are listed in Table 1. Typical elevation view of the bridge is shown in Fig. 1.

Table 1. Parameters of some piers.

\begin{tabular}{cccccccc}
\hline Pier No. & 3 & 4 & 5 & 6 & 7 & 8 & 9 \\
\hline $\begin{array}{c}\text { Height (m) } \\
\begin{array}{c}\text { Length of pile } \\
\text { foundation above } \\
\text { river bed (m) }\end{array}\end{array}$ & 24.4 & 27.6 & 20.1 & 27 & 26.7 & 26.5 & 26.2 \\
\hline
\end{tabular}

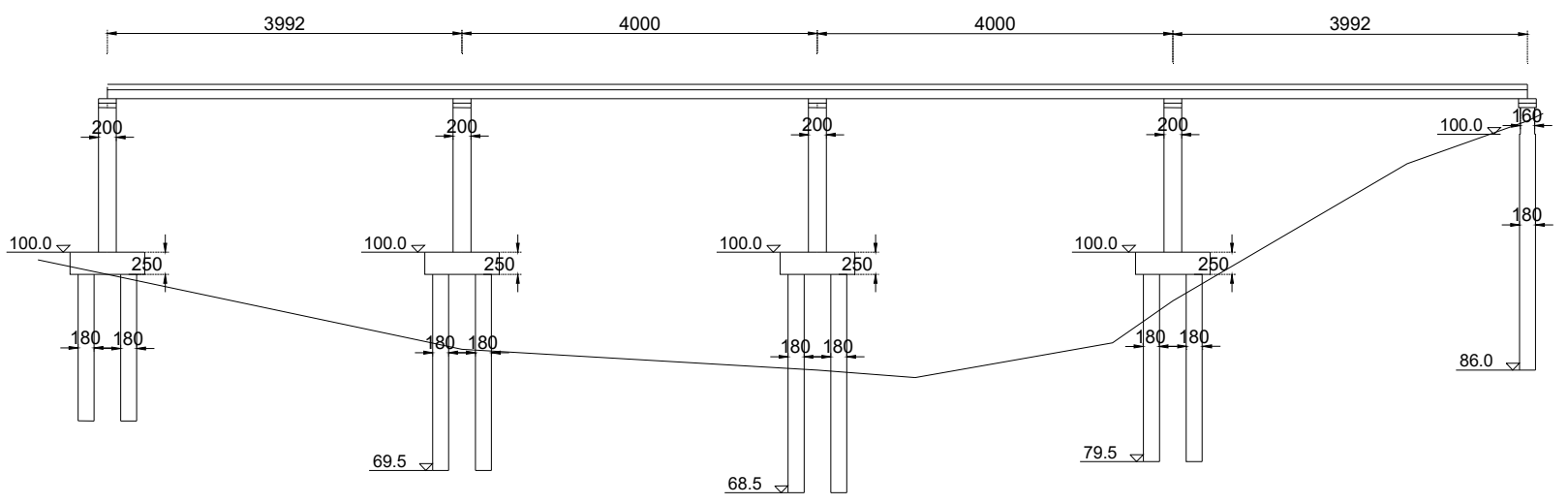

Fig. 1. Typical elevation view of the bridge.

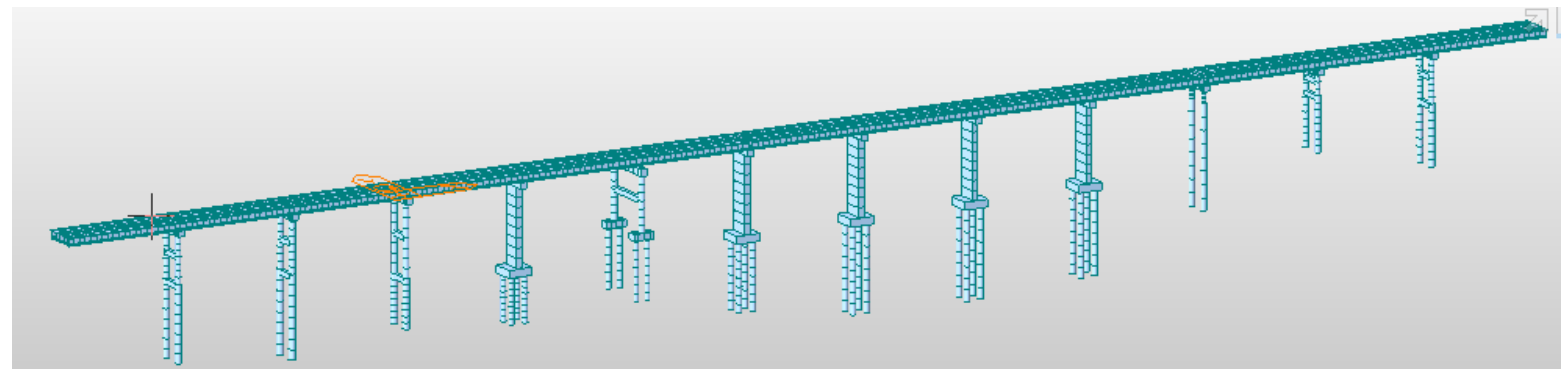

Fig. 2. Finite element model.

\section{Finite element model}

A full-bridge calculation model is established with a general finite element software. The superstructure is simulated using beam-shell combination model, the piers and foundation piles are simulated using beam element. The whole bridge is divided into 337 elements and 2242 nodes. The calculation model can be seen in Fig. 2.

\subsection{Material parameters}

Structural material properties are determined according to the bridge design parameters, C50 concrete is selected for the material parameter of main girder, C35 concrete for that of the pier and $\mathrm{C} 30$ concrete for the foundation pile.

\subsection{Bridge bearing simulation}

Elastic connection is used to simulate the Pot bearings of this bridge in calculation model, including the bilateral bridge bearing (SX), unidirectional bridge bearing (DX) and fixed bridge bearing (GD) according to the bridge design. For fixed bearing, the stiffness of the bearing in all directions is set to be $1 \times 10^{7} \mathrm{kN} / \mathrm{m}$. for bilateral bridge bearing and unidirectional bridge bearing, sliding is allowed when the horizontal force applied on the bearing exceeds the friction between the steel plate and PTFE sliding plate of the bearing. According to article 6.3.7 of "Guidelines for seismic Design of Highway Bridges" (JTG/TB02-01-2008), the restoring force of Pot-type elastomeric pad bearing is fitted out based on the bilinear form, as is shown in Fig. 3. 


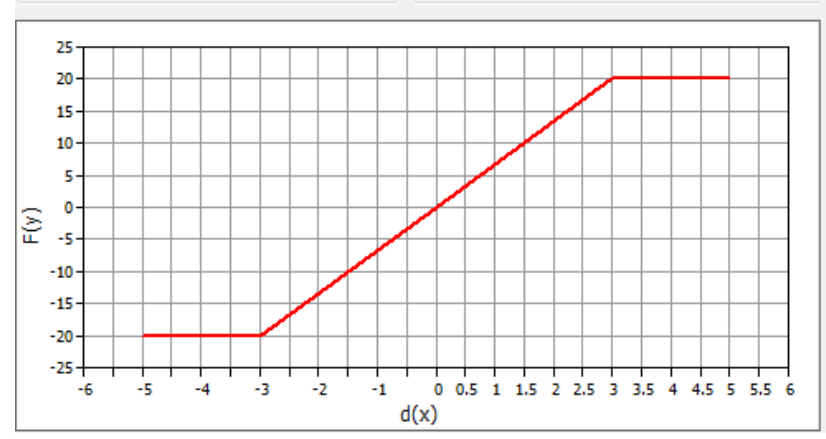

Fig. 3. Bearing friction model.

The yielding displacement of bearing is taken as $3 \mathrm{~mm}$. The friction coefficient of Pot-type elastomeric pad bearing is 0.03 . The critical sliding friction force can be adjusted according to the different bearing stress states. The initial horizontal shear stiffness of bearing is listed in Table 2.

Table 2. Initial horizontal shear stiffness of bearing. $(\mathrm{kN})$

\begin{tabular}{ccccc}
\hline Position & $\begin{array}{c}\text { Average } \\
\text { value of } \\
\text { reaction force } \\
\text { of single } \\
\text { bearing in } \\
\text { finished } \\
\text { bridge state }\end{array}$ & $\begin{array}{c}\text { Critical } \\
\text { sliding } \\
\text { friction } \\
\text { of single } \\
\text { bearing }\end{array}$ & $\begin{array}{c}\text { Yield } \\
\text { displace } \\
\text { ment of } \\
\text { bearing }\end{array}$ & $\begin{array}{c}\text { Initial } \\
\text { horizontal } \\
\text { shear } \\
\text { stiffness } \\
\text { of bearing }\end{array}$ \\
\hline $\begin{array}{c}\text { bearing } \\
\text { support } \\
\text { of side- } \\
\text { span } \\
\text { bearing } \\
\text { support } \\
\text { of mid- } \\
\text { span }\end{array}$ & 1091 & 33 & 0.003 & 11000 \\
\hline
\end{tabular}

\subsection{Pile-soil interaction simulation}

Pile-soil interaction is simulated by setting elastic support at nodes, which is achieved by input elastic support stiffness in the direction of six degrees of freedom of any node in the global coordinate system or the local coordinate system. The elastic support stiffness is calculated using $\mathrm{m}$ method, which is in appendix $\mathrm{P}$ for the Specifications for Design of Foundation of Highway Bridges and Culverts (JTG 3363-2019) ${ }^{[10]}$.

\section{Calculation Results and Analysis of Factors Influencing the Horizontal Displacement of Pier Top}

\subsection{Design load action}

According to the design drawings and relevant design specifications, the design loads which may affect the horizontal displacement of pier top under ideal conditions mainly include dead load, vehicle load, vehicle braking force and temperature load. Firstly, according to the requirements of design specifications, the size of each design load is determined. Then the horizontal displacement of each bridge pier top is calculated under the above design load. Calculation results are summarized in Table 3, and comparative analysis is carried out. The signs of the longitudinal horizontal displacement of the pier top and the bearing longitudinal friction are specified as follow: A plus sign indicates the large mileage direction, while minus sign indicates the small mileage direction.

It can be seen that under ideal conditions, dead load, vehicle load, braking force and temperature load have little effect on the horizontal displacement of pier top, especially the dead load and vehicle load. and the displacement of the pier top is within the allowable displacement range of the bearing.

\subsection{Bearing under eccentric compression}

For bridges with longitudinal slopes, the top plate and sliding surface of the support are horizontal under ideal conditions, as shown in Figure 4. When the embedded steel plate at the bottom of the beam is not levelled by wedge block in accordance with the longitudinal slope, The top plate of the support is directly welded on the embedded steel plate at the bottom of the beam, resulting in the uneven sliding surface, as shown in Figure 5. Due to the eccentric compression on bridge bearing, the force of the support opposing on the beam can be decomposed into the support force perpendicular to the beam and the friction force parallel to the support. The resultant force is equal to the vertical pressure of the beam acting on the support. Therefore, deflection of the bearing is used to simulate the effect of eccentric compression on bearing. The deflection angle is equal to the longitudinal slope angle of the beam. Longitudinal displacement of pier under the action of dead load, vehicle load, braking force and temperature load are shown in Table 5. Because the longitudinal gradient of this bridge is small $(0.7 \%)$, the deviation of each pier support changes little under bias.

\subsection{Under different bearing friction coefficient}

The degree of lubrication, corrosion, and wear between the contact surface of the bearing PTFE plate and the steel plate will affect the sliding friction coefficient. In the above analysis, the friction coefficient of Pot-type elastomeric pad bearing is taken as 0.03 according to the specification. Friction coefficient in this test is generally less than this value. Calculation results of the horizontal displacement of the pier top with friction coefficients taken as 0.01 and 0.02 respectively are shown in Table 6 . The displacement of pier top with three kinds of friction coefficient is compared and analysed. It can be seen that with the decrease of bearing friction coefficient, the displacement of fixed pier and joint pier increases under dead load and vehicle load, while the displacement of intermediate nonfixed-pier remains unchanged or decreases. With the decrease of friction coefficient, the displacement of fixed pier increases obviously under the action of braking force. As can be seen that the displacement of No.2 pier of the continuous beam before the first joint increased from $7.72 \mathrm{~mm}$ to $3.32 \mathrm{~mm}$. 


\subsection{Comparative analysis of load combinations}

Calculation results of longitudinal displacement of pier top by adding load combination effect and single load effect are listed in table 7 and table 8 respectively. It can be seen from the comparative analysis, the difference between NO.3 pier and NO.6 pier is the biggest. The longitudinal displacement of NO.3 pier increased from more than $1 \mathrm{~mm}$ to more than $6 \mathrm{~mm}$, and No.6 pier

Table 3. Horizontal displacement of each pier top caused by design load.

\begin{tabular}{|c|c|c|c|c|c|c|c|c|c|}
\hline \multirow{3}{*}{$\begin{array}{l}\text { Pier } \\
\text { NO. }\end{array}$} & \multicolumn{9}{|c|}{ Horizontal displacement of pier top ( $\mathrm{mm})$} \\
\hline & \multirow[b]{2}{*}{$\begin{array}{l}\text { Dead } \\
\text { load }\end{array}$} & \multirow{2}{*}{$\begin{array}{c}\text { Minimum value } \\
\text { caused by vehicle } \\
\text { load }\end{array}$} & \multirow{2}{*}{$\begin{array}{c}\text { Maximum value } \\
\text { caused by vehicle } \\
\text { load }\end{array}$} & \multicolumn{4}{|c|}{$\begin{array}{l}\text { Braking force of the vehicle acting on different } \\
\text { continuous beam }\end{array}$} & \multicolumn{2}{|c|}{ temperature load } \\
\hline & & & & $\begin{array}{c}\text { NO.1 } \\
\text { continuous } \\
\text { beam }\end{array}$ & $\begin{array}{c}\text { NO. } 2 \\
\text { continuous } \\
\text { beam }\end{array}$ & $\begin{array}{c}\text { NO.3 } \\
\text { continuous } \\
\text { beam }\end{array}$ & $\begin{array}{c}\text { NO.4 } \\
\text { continuous } \\
\text { beam }\end{array}$ & Heating up & $\begin{array}{l}\text { Cooling } \\
\text { down }\end{array}$ \\
\hline $1 \#$ & -0.48 & -6.51 & 0.42 & -6.51 & -1.29 & -0.40 & -0.01 & -3.69 & 3.69 \\
\hline $2 \#$ & 0.43 & -7.72 & 0.51 & -7.72 & -1.54 & -0.48 & -0.01 & 5.63 & -5.63 \\
\hline $3 \#$ & -0.09 & -4.73 & 0.98 & -4.73 & -3.66 & -1.15 & -0.03 & 0.05 & -0.05 \\
\hline $4 \#$ & -0.39 & -2.33 & 0.65 & -2.33 & -6.23 & -1.97 & -0.06 & -4.62 & 4.62 \\
\hline $5 \#$ & 0.54 & -2.32 & 0.78 & -2.32 & -6.23 & -1.98 & -0.06 & 5.41 & -5.41 \\
\hline $6 \#$ & -0.16 & -1.23 & 0.81 & -1.23 & -3.31 & -3.90 & -0.11 & 0.03 & -0.03 \\
\hline $7 \#$ & -0.43 & -0.48 & 0.54 & -0.48 & -1.30 & -6.91 & -0.20 & -10.73 & 10.73 \\
\hline $8 \#$ & -0.04 & -0.47 & 0.53 & -0.47 & -1.28 & -6.91 & -0.20 & -0.72 & 0.72 \\
\hline 9\# & 0.31 & -0.47 & 0.67 & -0.47 & -1.26 & -6.90 & -0.20 & 9.28 & -9.28 \\
\hline $10 \#$ & 0.02 & -0.07 & 0.67 & -0.07 & -0.18 & -0.52 & -0.44 & 0.00 & 0.00 \\
\hline $11 \#$ & -0.19 & -0.01 & 0.13 & -0.01 & -0.03 & -0.07 & -1.29 & -1.52 & 1.52 \\
\hline $12 \#$ & 0.59 & -0.02 & 0.66 & -0.02 & -0.06 & -0.16 & -2.95 & 6.49 & -6.49 \\
\hline
\end{tabular}

Table 4. Longitudinal friction of pier top bearing caused by design load.

\begin{tabular}{|c|c|c|c|c|c|c|c|c|c|}
\hline \multirow{4}{*}{ Pier NO. } & \multicolumn{9}{|c|}{ Longitudinal friction of pier top support $(\mathrm{kN})$} \\
\hline & \multirow{3}{*}{$\begin{array}{c}\text { Dead } \\
\text { load }\end{array}$} & \multirow{3}{*}{$\begin{array}{l}\text { Minimum value } \\
\text { caused by } \\
\text { vehicle load }\end{array}$} & \multirow{3}{*}{$\begin{array}{c}\text { Maximum value } \\
\text { caused by vehicle } \\
\text { load }\end{array}$} & \multicolumn{4}{|c|}{$\begin{array}{l}\text { Braking force of the vehicle acting on } \\
\text { different continuous beam }\end{array}$} & \multicolumn{2}{|c|}{ temperature load } \\
\hline & & & & NO.1 & NO. 2 & NO.3 & NO.4 & & Cooling \\
\hline & & & & $\begin{array}{l}\text { continuous c } \\
\text { beam }\end{array}$ & $\begin{array}{l}\text { ontinuous } \\
\text { beam }\end{array}$ & $\begin{array}{c}\text { ontinuous } \\
\text { beam }\end{array}$ & $\begin{array}{c}\text { continuous } \\
\text { beam }\end{array}$ & Heating up & down \\
\hline 3\#（1 ${ }^{\text {st }}$ union $)$ & -11.38 & 3.41 & -3.89 & -33 & 14.91 & 2.73 & 0.06 & -33 & 33 \\
\hline 3\#（2 $2^{\text {st }}$ union $)$ & 11.58 & 3.71 & -3.26 & 14.71 & -33 & -3.67 & -0.08 & 33 & -33 \\
\hline 6\#（2 $2^{\text {st }}$ union $)$ & -11.69 & 2.96 & -3.13 & -5.37 & -33 & 11.15 & 0.23 & -33 & 33 \\
\hline $6 \#\left(3^{\text {st }}\right.$ union $)$ & 11.99 & 3.21 & -3.2 & 3.19 & 11.89 & -33 & -0.41 & 33 & -33 \\
\hline $10 \#\left(3^{\text {st }}\right.$ union $)$ & -11.92 & 2.21 & -2.74 & -1.37 & -5.11 & -33 & 1.37 & -33 & 33 \\
\hline $10 \#\left(4^{\text {st }}\right.$ union $)$ & 12.11 & 3.33 & -2.2 & 0.11 & 0.41 & 1.63 & -33 & 33 & -33 \\
\hline
\end{tabular}




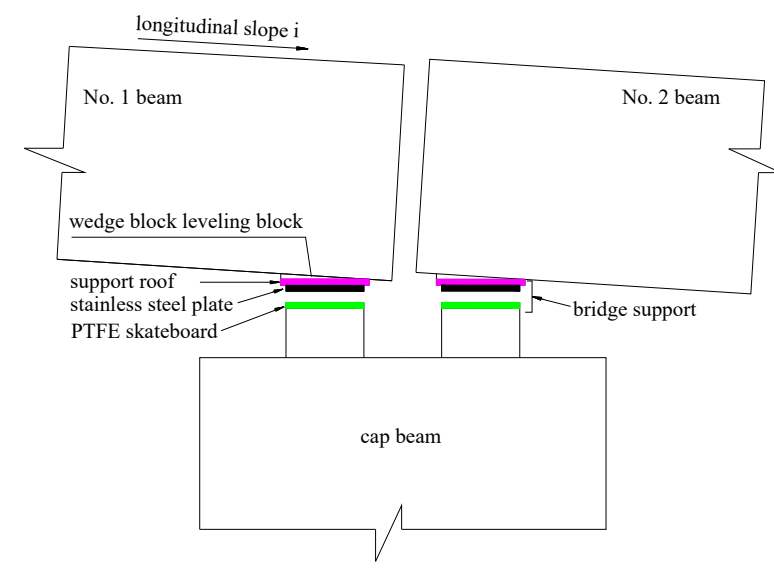

Fig. 4. diagram of ideal bearing installation level.

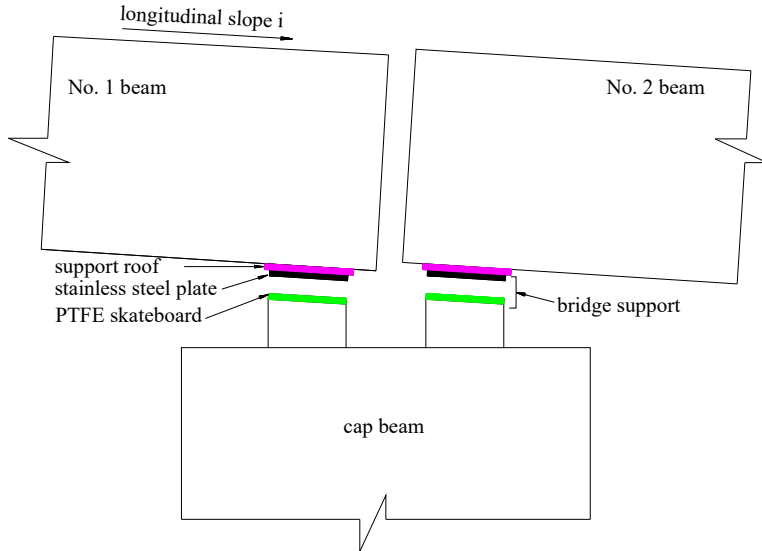

Fig. 5. Diagram of uneven installation of actual bearing.

Table 5. Horizontal displacement of each pier top caused by design load when bearing under eccentric compression.

\begin{tabular}{|c|c|c|c|c|c|c|c|c|c|}
\hline \multirow{3}{*}{$\begin{array}{l}\text { Pier } \\
\text { NO. }\end{array}$} & \multicolumn{9}{|c|}{ Horizontal displacement of pier top ( $\mathrm{mm})$} \\
\hline & \multirow[b]{2}{*}{$\begin{array}{l}\text { Dead } \\
\text { load }\end{array}$} & \multirow{2}{*}{$\begin{array}{c}\text { Minimum value } \\
\text { caused by vehicle } \\
\text { load }\end{array}$} & \multirow{2}{*}{$\begin{array}{l}\text { Maximum value } \\
\text { caused by vehicle } \\
\text { load }\end{array}$} & \multicolumn{4}{|c|}{$\begin{array}{l}\text { Braking force of the vehicle acting on different } \\
\text { continuous beam }\end{array}$} & \multicolumn{2}{|c|}{ temperature load } \\
\hline & & & & $\begin{array}{c}\text { NO.1 } \\
\text { continuous } \\
\text { beam }\end{array}$ & $\begin{array}{c}\text { NO.2 } \\
\text { continuous } \\
\text { beam }\end{array}$ & $\begin{array}{c}\text { NO.3 } \\
\text { continuous } \\
\text { beam }\end{array}$ & $\begin{array}{c}\text { NO.4 } \\
\text { continuous } \\
\text { beam }\end{array}$ & Heating up & $\begin{array}{l}\text { Cooling } \\
\text { down }\end{array}$ \\
\hline $1 \#$ & -0.48 & -0.90 & -0.68 & 0.50 & -6.51 & -1.29 & -0.40 & -0.01 & -3.69 \\
\hline $2 \#$ & 0.43 & 0.83 & -0.46 & 0.52 & -7.72 & -1.54 & -0.48 & -0.01 & 5.63 \\
\hline $3 \#$ & -0.09 & -0.20 & -1.05 & 1.03 & -4.73 & -3.66 & -1.15 & -0.03 & 0.04 \\
\hline $4 \#$ & -0.39 & -0.16 & -0.68 & 0.63 & -2.33 & -6.23 & -1.97 & -0.06 & -4.62 \\
\hline $5 \#$ & 0.54 & 0.78 & -0.67 & 0.73 & -2.32 & -6.23 & -1.98 & -0.06 & 5.41 \\
\hline $6 \#$ & -0.16 & -0.33 & -0.86 & 0.86 & -1.23 & -3.31 & -3.90 & -0.11 & 0.04 \\
\hline $7 \#$ & -0.43 & -0.18 & -0.59 & 0.52 & -0.48 & -1.30 & -6.91 & -0.20 & -10.73 \\
\hline $8 \#$ & -0.04 & 0.21 & -0.53 & 0.52 & -0.47 & -1.28 & -6.91 & -0.20 & -0.72 \\
\hline $9 \#$ & 0.31 & 0.56 & -0.54 & 0.62 & -0.47 & -1.26 & -6.90 & -0.20 & 9.28 \\
\hline $10 \#$ & 0.02 & 0.01 & -0.67 & 0.68 & -0.07 & -0.18 & -0.52 & -0.44 & 0.00 \\
\hline $11 \#$ & -0.19 & -0.37 & -0.18 & 0.14 & -0.01 & -0.03 & -0.07 & -1.29 & -1.52 \\
\hline $12 \#$ & 0.59 & 1.08 & -0.47 & 0.60 & -0.02 & -0.06 & -0.16 & -2.95 & 6.49 \\
\hline
\end{tabular}

Table 6. Horizontal displacement of each pier top caused by design load under different bearing friction coefficient. (mm)

\begin{tabular}{|c|c|c|c|c|c|c|c|c|c|c|c|c|c|c|c|c|c|}
\hline \multirow{3}{*}{$\begin{array}{l}\text { Pier } \\
\text { NO }\end{array}$} & \multirow{3}{*}{$\begin{array}{c}\text { Dead load } \\
0.020 .01\end{array}$} & \multirow{2}{*}{\multicolumn{2}{|c|}{$\begin{array}{l}\text { Minimum } \\
\text { value caused } \\
\text { by vehicle } \\
\text { load }\end{array}$}} & \multirow{2}{*}{\multicolumn{2}{|c|}{$\begin{array}{c}\text { Maximum } \\
\text { value caused } \\
\text { by vehicle } \\
\text { load }\end{array}$}} & \multicolumn{8}{|c|}{ Braking force of the vehicle acting on different continuous beam } & \multicolumn{4}{|c|}{ temperature load } \\
\hline & & & & & & \multicolumn{2}{|c|}{$\begin{array}{l}\text { NO. } 1 \text { continuous } \\
\text { beam }\end{array}$} & \multicolumn{2}{|c|}{$\begin{array}{l}\text { NO. } 2 \text { continuous } \\
\text { beam }\end{array}$} & \multicolumn{2}{|c|}{$\begin{array}{c}\text { NO. } 3 \text { continuous } \\
\text { beam }\end{array}$} & \multicolumn{2}{|c|}{$\begin{array}{l}\text { NO. } 4 \text { continuous } \\
\text { beam }\end{array}$} & \multicolumn{2}{|c|}{ Heating up } & \multicolumn{2}{|c|}{ Cooling down } \\
\hline & & 0.02 & 0.01 & 0.02 & 0.01 & 0.02 & 0.01 & 0.02 & 0.01 & 0.02 & 0.01 & 0.02 & 0.01 & 0.02 & 0.01 & 0.02 & 0.01 \\
\hline $1 \#$ & $\overline{-}^{-}-0.37$ & -0.61 & -0.50 & 0.47 & 0.40 & -10.52 & -5.38 & -1.16 & -0.62 & -0.23 & -0.07 & -0.01 & 0.00 & -3.57 & -3.25 & 3.57 & 3.25 \\
\hline $2 \#$ & 0.430 .42 & -0.49 & -0.55 & 0.54 & 0.59 & -13.45 & -33.32 & -1.49 & -0.96 & -0.29 & -0.10 & -0.01 & 0.00 & 5.44 & 4.96 & -5.44 & -4.96 \\
\hline $3 \#$ & $0.10^{-0.12}$ & -1.22 & -1.65 & 1.21 & 1.66 & -3.94 & -2.80 & -3.79 & -2.88 & -0.75 & -0.30 & -0.02 & 0.00 & 0.05 & 0.06 & -0.06 & -0.06 \\
\hline $4 \#$ & $0.40^{-0.42}$ & -0.68 & -0.66 & 0.63 & 0.64 & -1.67 & -0.85 & -8.83 & -12.44 & -1.35 & -0.62 & -0.03 & -0.01 & -4.63 & -4.63 & 4.63 & 4.63 \\
\hline $5 \#$ & 0.530 .50 & -0.67 & -0.67 & 0.74 & 0.76 & -1.67 & -0.85 & -8.84 & -12.45 & -1.36 & -0.63 & -0.03 & -0.01 & 5.41 & 5.42 & -5.41 & -5.42 \\
\hline $6 \#$ & $\overline{-}^{-} 7^{-0.19}$ & -0.95 & -1.16 & 0.94 & 1.15 & -0.80 & -0.33 & -2.80 & -1.90 & -3.09 & -1.99 & -0.07 & -0.02 & 0.03 & 0.03 & -0.03 & -0.03 \\
\hline
\end{tabular}




\begin{tabular}{|c|c|c|c|c|c|c|c|c|c|c|c|c|c|c|c|c|}
\hline $7 \#$ & $0.42^{-0.41-0.54}$ & -0.46 & 0.48 & 0.41 & -0.27 & -0.08 & -0.95 & -0.47 & -9.67 & -12.46 & -0.14 & -0.05 & -10.74 & -10.75 & 10.74 & 10.75 \\
\hline $8 \#$ & $0.04^{-0.04-0.50}$ & -0.45 & 0.50 & 0.44 & -0.27 & -0.08 & -0.94 & -0.46 & -9.67 & -12.46 & -0.14 & -0.05 & -0.73 & -0.73 & 0.73 & 0.73 \\
\hline $9 \#$ & $\begin{array}{lll}0.30 & 0.30 & -0.50\end{array}$ & -0.44 & 0.58 & 0.50 & -0.27 & -0.08 & -0.93 & -0.46 & -9.66 & -12.46 & -0.14 & -0.05 & 9.29 & 9.30 & -9.29 & -9.30 \\
\hline $10 \#$ & $\begin{array}{lll}0.02 & 0.02 & -0.69\end{array}$ & -0.71 & 0.69 & 0.72 & -0.03 & 0.00 & -0.10 & -0.03 & -0.36 & -0.19 & -0.37 & -0.19 & 0.00 & 0.00 & 0.00 & 0.00 \\
\hline $11 \#$ & $0.16^{-0.11-0.14}$ & -0.08 & 0.11 & 0.07 & 0.00 & 0.00 & -0.01 & 0.00 & -0.03 & -0.01 & -1.55 & -0.77 & -1.39 & -0.77 & 1.39 & 0.77 \\
\hline $12 \#$ & $\begin{array}{lll}0.57 & 0.51 & -0.44\end{array}$ & -0.39 & 0.56 & 0.49 & -0.01 & 0.00 & -0.03 & -0.01 & -0.10 & -0.04 & -5.27 & -13.41 & 5.91 & 3.30 & -5.91 & -3.30 \\
\hline
\end{tabular}

Table 7. Calculation results of longitudinal displacement of pier top under load combination.

\begin{tabular}{cccccccccc}
\hline item & friction coefficent & $1 \#$ & $2 \#$ & $3 \#$ & $4 \#$ & $5 \#$ & $6 \#$ & $7 \#$ & $8 \#$ \\
\hline maximum & 0.03 & 3.54 & 6.35 & 6.30 & 4.27 & 6.15 & 2.22 & 10.60 & 0.95 \\
displaceme & 0.02 & 3.44 & 6.15 & 6.30 & 4.27 & 6.15 & 2.22 & 10.61 & 0.95 \\
nt & 0.01 & 3.14 & 5.63 & 6.31 & 4.28 & 6.16 & 2.22 & 10.63 & 0.95 \\
minimum & 0.03 & -4.28 & -5.15 & -6.66 & -5.18 & -5.12 & -2.79 & -11.15 & -0.98 \\
displaceme & 0.02 & -4.15 & -4.99 & -6.66 & -5.19 & -5.12 & -2.79 & -11.16 & -0.98 \\
nt & 0.01 & -3.80 & -4.57 & -6.67 & -5.19 & -5.13 & -2.79 & -11.17 & -0.99 \\
\hline
\end{tabular}

Table 8. Calculation results of longitudinal displacement of pier top under the effect of single load (dead load + cooling down temperature load + vehicle load).

\begin{tabular}{|c|c|c|c|c|c|c|c|c|c|}
\hline item & $\begin{array}{r}\text { pier NO. } \\
\text { friction coefficent }\end{array}$ & $1 \#$ & $2 \#$ & $3 \#$ & $4 \#$ & $5 \#$ & $6 \#$ & $7 \#$ & $8 \#$ \\
\hline maximum & 0.03 & 3.71 & 6.58 & 0.88 & 4.85 & 6.67 & 0.66 & 10.82 & 1.20 \\
\hline displaceme & 0.02 & 3.59 & 6.41 & 1.05 & 4.86 & 6.68 & 0.74 & 10.8 & 1.19 \\
\hline $\mathrm{nt}$ & 0.01 & 3.28 & 5.97 & 1.48 & 4.85 & 6.68 & 0.93 & 10.75 & 1.13 \\
\hline minimum & 0.03 & -4.84 & -5.66 & -1.08 & -5.69 & -5.54 & -0.99 & -11.75 & -1.29 \\
\hline displaceme & 0.02 & -4.63 & -5.5 & -1.27 & -5.71 & -5.55 & -1.09 & -11.7 & -1.27 \\
\hline nt & 0.01 & -4.12 & -5.09 & -1.71 & -5.71 & -5.59 & -1.32 & -11.62 & -1.22 \\
\hline
\end{tabular}

\section{Conclusion}

Based on the typical high-pile and high-pier bridge crossing the reservoir area in Chun'an section of Qianhuang expressway, the factors influencing the horizontal displacement of pier top are analyzed through calculation in this paper, and the following are the conclusions:

(1) Through the analysis of the influence of dead load, vehicle load, vehicle braking force and temperature load on the pier top deflection under the design state, it can be seen that in single load action state, dead load, vehicle load has less influence on the pier top deflection, while braking force and temperature load have greater influence. However, the displacement of the pier top is within the allowable range of the bearing. After unloading, the pier and the bearing should be able to restore to their original position.

(2) Because the longitudinal gradient of the bridge is quite small $(0.7 \%)$, the deviation of each pier support changes little when bridge bearing is under eccentric compression.

(3) With the decrease of bearing friction coefficient, the displacement of fixed pier and connecting pier increases, while that of the intermediate nonfixed-pier remains unchanged or decreases under the action of dead load and vehicle load, the displacement of the fixed pier increases significantly under the action of braking force, with the friction coefficient decreases from 0.03 to 0.01 , the displacement of No.2 pier in No.1 jointed continuous beam increases from 7.72 $\mathrm{mm}$ to $33.32 \mathrm{~mm}$.

(4) Due to the nonlinear development of the friction force, the displacement of the joint pier increases significantly under the combination load, which indicates that after the sliding of the bearing caused by the temperature load, the effect of the vehicle load on the horizontal deflection of the pier top can reach the maximum. When the support is damaged, displacement of the joint pier top caused by vehicle load may accumulate, result in the continuous increase of the deflection of joint pier, While that of the intermediate pier is not obvious.

\section{Acknowledgements}

The research work presented herein is sponsored by Scientific Research Project of Zhejiang Provincial Department of Transportation (2020-GCKY-01) .

\section{References}

1. S.K. Jiang, Structural performance analysis and limit structure research of high pile and high pier of deep water bridge, (2020) 
2. S.K. Jiang, L. Q. Zhang, H. J. Lou, Research and Analysis on horizontal displacement calculation and limit control of high pier of bridge, Highway transportation technology, 1(2020)

3. W.J. Gao, C.C. Xu, Treatment and reinforcement of pier deviation of a continuous beam bridge, Highway transportation technology, 6, 80-83(2012)

4. J.W. Guo, Study on the causes of pier deflection and stability safety of continuous girder bridge, (2020)

5. S. Xu, Study on Causes and solutions of pier deflection of poqiao Bridge, (2015)

6. S. Q. Tian, J.X. Wang, Q.F. Shi, Research on the relationship between bearing installation defects and pier deflection, Chinese and foreign highways, 35(6), 179-181(2015)

7. H. Y. Wu, Analysis and rectification of pier deflection of high pier bridge, Northern transportation, 12, 3740(2019)

8. W. L. Sun, S. C. Li, Cause analysis and treatment suggestions of a bridge pier column deviation, Northern transportation, 7, 39-42(2013)

9. L. H. Wang, X. Zhang, W. Y. Zheng, Analysis on horizontal displacement of top of beam pier with high and low piers in mountainous area, Journal of Zhejiang communications Polytechnic, 21, 01:510(2020)

10. Specifications for Design of Foundation of Highway Bridges and Culverts (2019) 